\title{
Achievements And Standards Of Quality In Secondary Schools In The Republic Of Kosovo
}

\author{
Hajrije Kastrati, Ph.D. \\ shipi10@live.com
}

\section{DOI:10.5901/mjss.2014.v5n19p518}

\begin{abstract}
Standards of quality in education today represent a major tool that enhances the quality of education and makes it more controllable. In order to successfully integrate Kosovo into European education is important for schools to have high quality achievement so this quality would be the same quality of education as in developed countries In this scientific paper will be presented: a) The quality of students' achievements (based on quality indicators as: the passing rate of graduation test and GPA of students) in some secondary schools in Kosovo. b) How satisfied are students with the quality and knowledge they acquired in those schools where the research was done and c) Are the schools in Kosovo implementing the European standards of education. The purpose of this paper will be the achievements and quality standards of education in Kosovo and are approximate quality of education with countries possessing European standards At the beginning of the paper will present in general for education quality standards while the main part will be the evaluation of distributed questionnaires in some high schools in Kosovo and basing on the results of the evaluation there will be also the recommendations.
\end{abstract}

Keywords: standards, quality, student achievement, schools, education.

\section{INTRODUCTION}

Currently the education sector is in the Republic of Kosovo is characterized by intense reform efforts aimed at the achievement of high-quality education. The increased interest in quality and standards is not only a matter of education system in Kosovo but also in many countries of the world.

According to the law no. 04/L-032 for undergraduate education in the Republic of Kosovo, standards are measurable indicators of defined success, in the form of qualitative or quantitative criteria, which are expected to be achieved by candidates in order for them to gain qualifications and standards of schools representing the concept of quality education which aims more at the quality of students, teaching, level of achievement etc.

Rating for achieving a certain standard is difficult without relying on specific indicators that demonstrate achievement of the relevant standards. As an indicator of the quality of education in Kosovo are: graduation test pass rate and average grade of students.

Achievements of the quality is conformity of specifications, which means precise measurement of efficiency and education institutions talk about providing quality services, which means that higher education institutions should adhere to the standards and requirements, provide educational programs and expect to provide excellent qualifications. So according to the dictionary education "education quality is assessment and educational level of effectiveness in achieving quality education"

\section{AIM OF THIS PAPER}

School Standards represent the concept of quality education which aims more at the quality of students, teaching, level of achievement etc.

The purpose of this research paper is the achievement and standards of quality in undergraduate education in Kosovo and factors affecting quality improvement in students

\section{PURPOSE AND ROLE OF STANDARDS}

"The standards define expectations to be achieved in education, it sets the criteria and requirements that schools must meet, determine what criteria should know and do, parties of interest in the education system, in order to achieve quality 
education, also serve to assess and self-assess the development and effectiveness of school ", this sentence quoted author (Darling-Hammond, 2012) which is also the author of many books that devote quality in education. While, according to a group of authors (VN Gordon, 2011), standards enable control, assessment of knowledge acquired, and enable control of educational work

The main goal of standard setting is:

- Determination of expectations for students and teachers in key areas of knowledge,

- Assignment of duties and work that be had by an school principals,

- Helping teachers in different directions professional development

- Increase quality of operation and implementation of the educational activities of the institution,

- Proper involvement of family, community and school in the institution.

Standards serve:

- drafting of curricula for high schools,

- To improve the various fields related to the management of the school

- Assist teachers in planning educational activities,

- Ensure that they meet the requirements set out teachers and other educational factors,

- Qu - Enable examination and assessment of knowledge acquired, skills and attitudes possessed,

- Enable control of educational work among teachers within the educational institution.

Evaluation to achieve a certain standard is difficult without relying on specific indicators showing the relevant standards.

1. Management and governance indicators are grouped into which measure and assess the performance of managerial staff of the school.

2. Capacity of school grouped indicators which measure and assess which aspects of competence such as schools offer teachers professional service competencies.

3. Curriculum and learning process-grouped indicators which measure and evaluate curriculum and teaching methods for the realization of the situation with instructional materials combined to control technology and engineering education.

\section{QUALITY EDUCATION-OPINIONS AND MODELS OF MANY LEARNERS}

Unfortunately there is no "recipe" for educational quality since quality is the result of many factors that are interrelated and influence each other reciprocally. The quality of education in schools is a roadmap for measurable outcomes of student success and closely reflected in the quality of the school. Therefore, all areas for the development of a good school are more or less necessary to achieve a high quality education. Areas affecting the quality of education are; leadership and management, Comprehensiveness, a strategy for the development of quality, professionalism, results and successes, school culture, etc..

Many researchers have analyzed the data to find out how to measure quality in education trying to identify factors that function as an indicator for the entire system, so to find a "representation" of the quality of education, which is an important indicator, measurable, easily accessible and can be measured over a period of time to document change.

The authors (Reeves, Carol; Bednar, David A, 1994) define "quality as excellence, showing high achievement standards, with attributes of excellence". While according to the author (Pirsig, 1974) "quality is difficult to define and is an elusive concept."

Researchers (Kavarkoglu, 1996) \& (B.Crosby, 1979) state that "the quality and standards are both inseparable". While (Henry) states that "the quality of education depends on its planning so planning is one of the highlights of the quality of education".

(Yildirim, 2002) states that "school quality of being suitable for standards" 
In his landmark text, "Quality of Education in Developing Countries", the author (Beeby, 1966) made the first attempt to generate a model for understanding the theory of education. He introduced the concept of quality on three criteria;

First, the "quality-class", which has to do with the acquisition of knowledge and measurable learning, and assessment of behaviors and attitudes of students and teachers which is very difficult to measure

Second, the "quality-education" which serve to economic goals of the community in which students live so the quality of education should serve economic goals

Thirdly to become quality control

According to his criterion of the second and third sets to quality education as "external quality" where the first criterion defines as "internal quality" which according to the author Beeby depends on several factors. As the main factors that influence the quality in education by the author are:

1. responsibility of the school (the school principal)

2. teachers and

3. income

He wrote this pattern when human capital theorists had begun development of quantitative techniques to measure the economic benefits of investment in education and so was motivated to propose a model of quality in education that match the sophistication of their analysis statistical. It was also a time when rapid expansion of education delivery, especially in countries with low income was perceived as a threat to quality education.

While the author (Sayed, 1997) in his book "The concept of quality in education", stated that four elements exist for an effective school;

- 1. Academic environment,

- 2. Learning of students,

- 3. Instructional leadership and

- 4. Use of school materials.

\section{ACHIEVEMENTS OF PASSAGE OF TEST AND PUPIL AVERAGE GRADE}

As an indicator of the quality of students in secondary schools in the Republic of Kosovo are the graduation test pass rate and average grade of the students. In this scientific paper will present a table through graduation test negotiability and the average grade of students for four years.

\begin{tabular}{|l|l|l|}
\hline Schooltime & Passing rate of graduation test & Average grade pupils \\
\hline $2010 / 11$ & 42.8 & 2.8 \\
\hline $2011 / 12$ & 52.9 & 1.6 \\
\hline $2012 / 13$ & 67.4 & 3.2 \\
\hline $2013 / 14$ & 52.5 & \\
\hline
\end{tabular}

\section{Methodology of the paper}

In this paper scientific methodology questionnaires will be working with who will collect primary data. The questionnaires will be disseminated in some of the top high schools in the Republic of Kosovo where the total number of questionnaires will be a total of 400 will be two types of survey; questionnaires for teachers and students and there are five questions every questionnaire.

Distribution of the questionnaire will be made after the consent of MEST (Ministry the Education Science and Technology) and DA's (Department the Education). Schools that will participate in this research are:

a) Economic high school "Ymer Prizreni"-Prizre 
b) General high school "Sami Frasheri"-Prishtine

c) General high school "Jeta E Re" - Therande

d) General high school "Xhelal Hajda-Toni- Rahovec

In the begging we will present test passing rate and the average grade of students in four high schools and then the data collected by questionnaires.

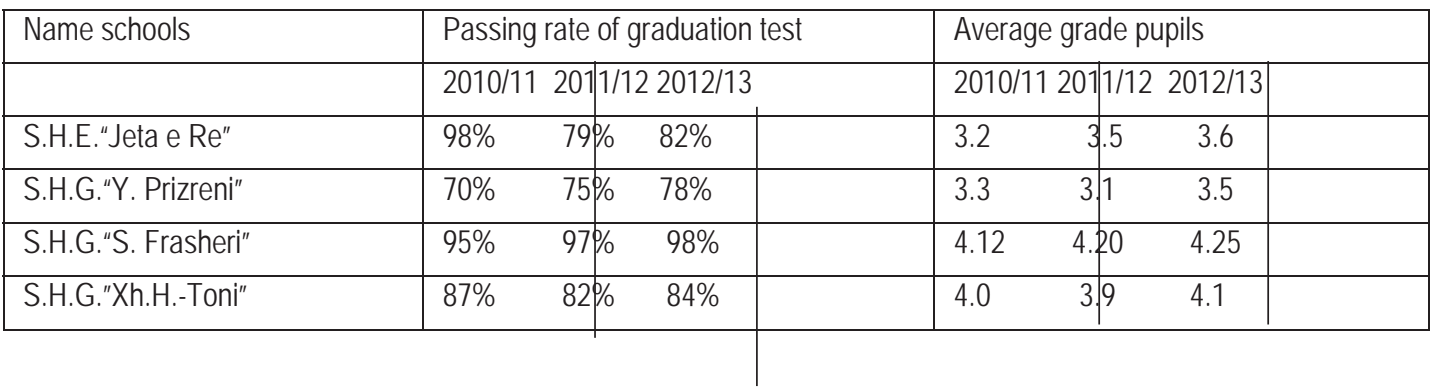

So, in this table are shown the average grade of the students and of graduation test pass rate for the past three years, while the data collected from the questionnaires will be in attendance to present the chapter.

\section{ANALYSIS}

In the first question; In your school has a high quality education?, About $65 \%$ of the respondents were in favor while $35 \%$ not for of present this is also in the form of a diagram

\section{In your school has a high quality education?}

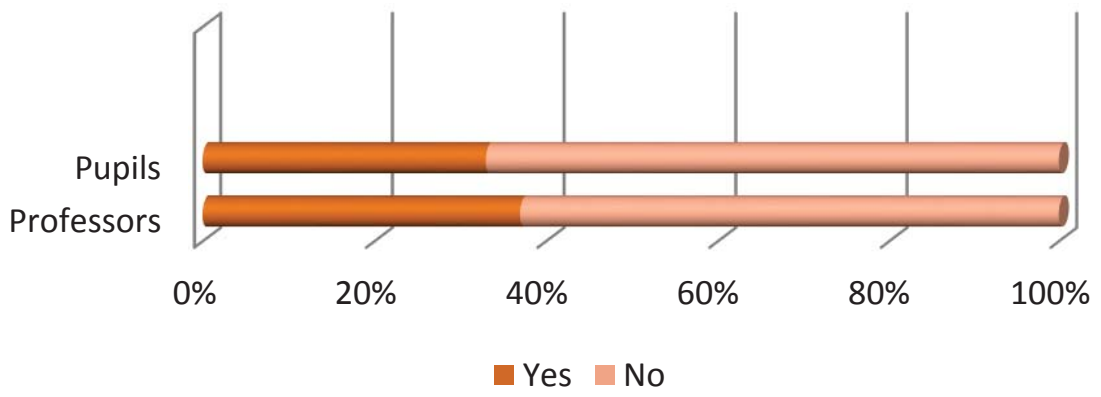

In the second question: Your school is led by a European Standards?, Where the answer was $69 \%$ while $31 \%$ for not being of this result for the present in the diagram below. 


\section{Your school is led by a European standards?}

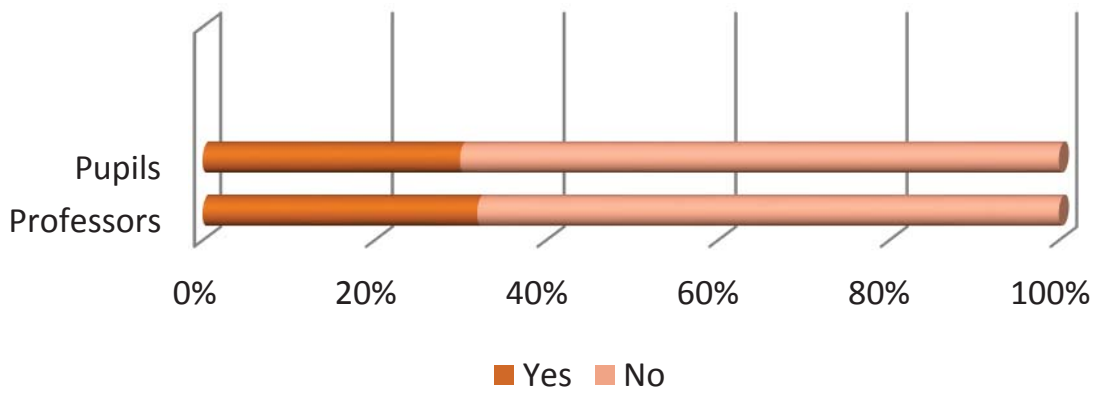

Third question: Secondary schools in Kosovo he meet quality standards in education?, where about $70 \%$ answered no while $30 \%$ answered yes.

\section{Secondary schools in Kosovo he meet quality standaeds in education?}

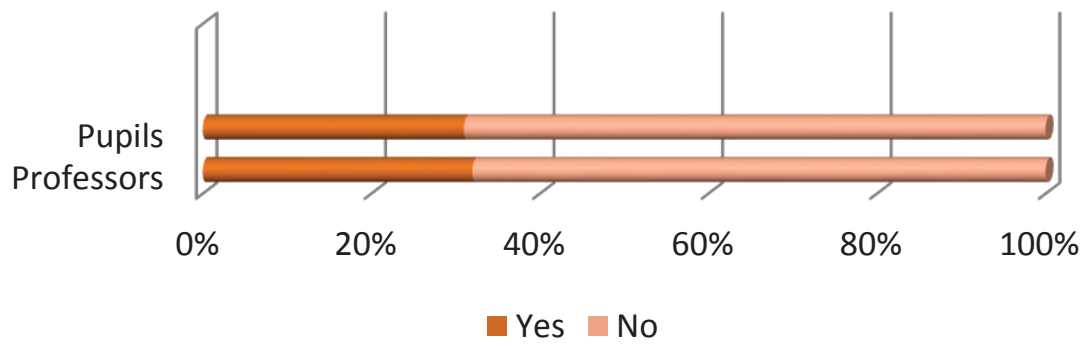

In the fourth question; Do you think that you the best quality management de Schools Will Bring Higher Achievements in education?, Where respondents answered affirmatively while the last question Do you think that you the Implementation of Standards in Education Will Be the Highest Achievement of quality?, Where the answer was about $90 \%$ for yes and only $10 \%$ for this result is not shown in the diagram.

\section{Do you think that the implementation of standards in education will be the highers achivement of quality?}

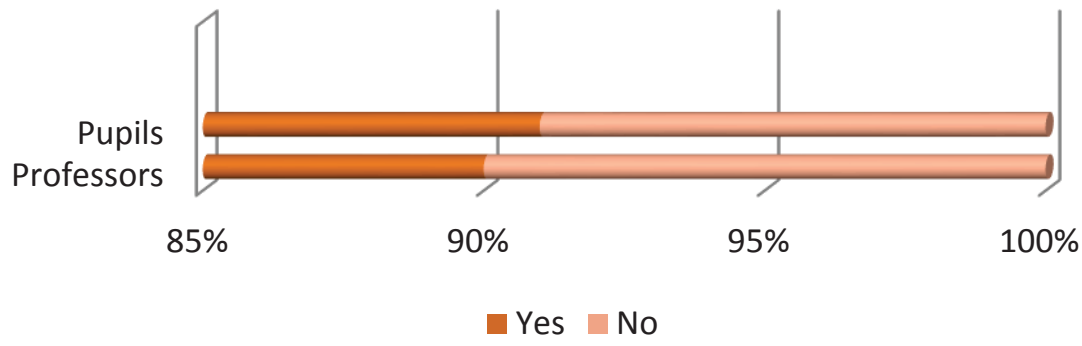




\section{RECOMMENDATIONS}

According to data obtained from questionnaires that were answered about 400 students and teachers come these recommendations:

- Schools of the Republic of Kosovo must be engaged more to improve the quality of education,

- To achieve the highest quality should engage directors, teachers and parents

- Since schools to apply standards which lead to the achievement of the highest quality and compare it to European and developed countries

- Perform implementation of new curricula with those evpropiane etc..

\section{General recommendations:}

Increasing the quality of university education in Kosovo is based on several factors, such as through the development of more effective legislation, the establishment of a peer review of school performance, a quality curriculum, an effective and efficient decision making, management of good excellence, professional training schools and professors who directly affect the quality of students. Professors engaged in looking not only for professional development, but also the professional training of high quality

\section{BIBLIOGRAFY}

1.B.Crosby, P. (1979). Quality is Free. New York: New American Library.

Beeby, C. (1966). The quality of education in developing countries. Harvard Universitety Press.

Darling-Hammond. (2012). Creating a Comprehensive System for Evaluating and Supporting Effective Teaching. Stanford University.

Henry, T. (n.d.).

Kashua, S. (1997).

Kavarkoglu, I. (1996). Total Quality Managment. Instabull.

Pirsig, R. M. (1974). Quality.

Reeves,Carol;Bednar,David A. (1994, July). Defining Quality:Alternalives and implications. Academy of Managment Review, pp. 419-445.

Sayed, Y. (1997). The concept of quality in education. London.

V.N. Gordon, W. H. (2011). Academic advising:A comprehensive hand book. USA.

Yildirim, A. (2002). Quality. NATIONAL REPORT ON UNIVERSITY LIFE LONG LEARNING. Ankara. 